J. Perinat. Med. $12(1984) 167$

\section{Plasma angiotensin II and blood pressure changes during dietary sodium manipulation}

\author{
M. I. Lee, R. J. Sokol, H. Todd*
}

Department of Obstetrics and Gynecology, Hutzel Hospital, Wayne State University, Detroit, Michigan, USA

* Department of Obstetrics and Gynecology, St. Louis University, St. Louis Missouri, USA

\section{Introduction}

The renin-angiotensin system has been repeatedly implicated in the pathogenesis of pregnancy induced hypertension $(\mathrm{PIH})[8,12,13]$. On a molecular basis, angiotensin II (A-II) is the most potent vasoconstrictor currently described. Increases in the circulating levels of this substance, as well as increases in vascular sensitivity to its pressor effect, may be involved in the pathogenesis of the hypertension observed in PIH. Subjects with PIH demonstrate marked retention of sodium [2], and A-II is known to stimulate adrenal secretion of the sodium sparing hormone, aldosterone [10]. Plasma levels of A-II are elevated in normal pregnancy, but reported levels of PIH are in conflict. WEIR et al. [14], found A-II levels significantly lower in hypertensive gravidas when compared to controls of similar gestation. However, SYMOND et al. [11], found a positive correlation between levels of plasma A-II and diastolic blood pressure in women with PIH.

In the non-pregnant state, blood pressure and plasma A-II are functions of sodium balance [1], but less is known about their interrelationship during pregnancy. To further investigate the role of sodium balance on the interrelationship between plasma A-II and blood pressure during pregnancy, we returned to a familiar animal model, the New Zealand white rabbit, in which plasma levels of A-II and blood pressure responses to infused doses of this hormone are similar to those found in human gestation [7].

\section{Methods}

Complete data was obtained from 23 of 30 animals originally selected for this study. The primigravid rabbits were at 24-28 days gestation (term $=30 \pm 1)$ and weighed 3-5 kilograms. We have previously found blood pressure and sodium balance can be altered by feeding these animals one of three diets for 8 days prior to operation and continuing the respective diets throughout the investigation until delivery [6]. The following protocol was implemented: 7 were fed Purina rabbit chow ( $0.4 \%$ sodium), and permitted to drink $0.9 \%$ saline; 9 were continued on regular rabbit chow ( $0.4 \%$ sodium) and tap water ad libitum; and 7 were fed trace sodium diet (Purina 5881-R) and deionized water ad libitum. Urines were collected for 24 hours just prior to surgery, centrifuged at $2000 \mathrm{rpm}$ for 5 minutes, and filtered before storing at $4{ }^{\circ} \mathrm{C}$ until sodium concentration was determined.

The animals were anesthetized and surgically prepared according to methods described elsewhere [7]. An indwelling catheter was placed in the carotid artery and connected to a $8805 \mathrm{C}$ 
HEWLETT-PACKARD recorder via a STATHAM P 23 1 a transducer. Following 20 minutes of stabilization, blood pressures and samples were obtained from the catheter over a 5 minute period. Mean arterial pressures were recorded during the first and fifth minutes, and $4 \mathrm{ml}$ of blood were slowly collected during the second, third and fourth minutes. Part of the specimen was suitably mixed in chilled tubes containing EDTA and preserved for A-II determination and part was permitted to stand and clot for serum sodium analysis. The specimens were stored at $-20^{\circ} \mathrm{C}$ until assayed.

Urinary sodium concentration was determined by flame photometry using a Radiometer FLM-3 instrument, and serum sodium levels were determined on the TECHNICON C 800. Plasma A-II levels were determined by radioimmunoassay according to methods described by GOODFRIEND et al. [5]. Assayed specimens were run in duplicate.

Statistical analysis was done using one-way analysis of variance and by determining correlation coefficients. A p $<.05$ was considered significant.

\section{Results}

The effects of dietary sodium manipulation are shown in Tab. I.

Urinary excretion of sodium differed significantly among the three groups $(p<.005)$. Urinary sodium loss was highest in the sodium loaded group when compared to control and sodium restricted groups. Serum sodium concentration was also altered by this dietary protocol $(\mathrm{p}<.005)$, and was lowest in the salt restricted group.

The effects of the three dietary protocols on baseline mean arterial pressure resulted in an increase

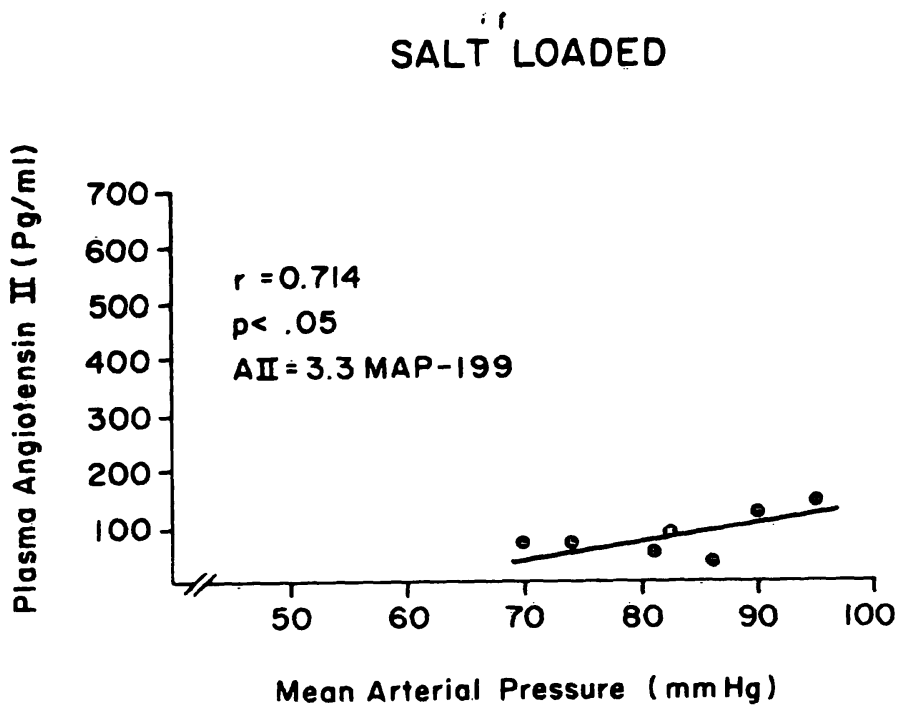

Fig. 1. The relationship between mean arterial blood pressure and plasma angiotensin II in dietary sodium loaded rabbits $(n=7)$ during late pregnancy.

\section{SALT RESTRICTED}

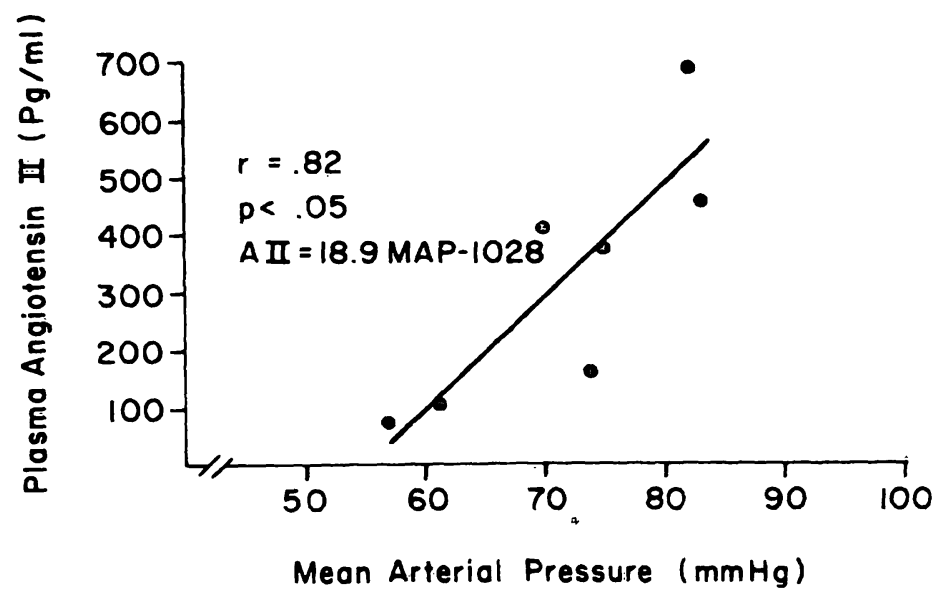

Fig. 2. The relationship between mean arterial pressure and plasma angiotensin II in dietary sodium restricted $(n=7)$ pregnant rabbits during late gestation.

in blood pressure in the sodium loaded group, when compared to control and sodium restricted groups. This difference is significant, $(\mathrm{p}<.025)$.

Tab. I. Urinary excretion of sodium, serum sodium, baseline mean arterial pressure (BMAP) and plasma angiotension II (A-II) in the salt loaded (SL), controls (C), and salt restricted (SR) animals.

\begin{tabular}{lcccc}
\hline Rabbit & Urine $(\mathrm{Na})(\mathrm{mM} / \mathrm{L})$ & Serum $(\mathrm{Na})(\mathrm{mM} / \mathrm{L})$ & BMAP $(\mathrm{mm} \mathrm{Hg})$ & A-II (pg/ml) \\
\hline SL $(\mathrm{n}=7)$ & $237 \pm 30$ & $143 \pm 2$ & $83 \pm 3$ & $78 \pm 15$ \\
C $(\mathrm{n}=9)$ & $26 \pm 6$ & $139 \pm 0.4$ & $67 \pm 3$ & $161 \pm 34$ \\
SR $(\mathrm{n}=7)$ & $5 \pm 2$ & $133 \pm 2$ & $72 \pm 3$ & $325 \pm 85$ \\
& $\mathrm{~F}=46.26$ & 10.30 & 5.97 & 5.53 \\
& P $<\quad .005$ & .005 & .025 & .025 \\
\hline
\end{tabular}


The correlations between plasma A-II levels and blood pressures were positive for all three groups. Correlation between plasma A-II and mean arterial pressure in the salt loaded animals was 0.714 $(p<.05)$, although levels of the hormone were lowest in this group of primigravidas. This relationship is shown in Fig. 1. As shown in Fig. 2, similar results were obtained in the salt restricted animals with a positive correlation of $0.82(p<.05)$, and levels of the hormone were highest in this group. The relationship between plasma A-II and mean arterial pressure was not significant, however, in the control group.

\section{Discussion}

The renin-angiotensin system and aberrations in sodium balance regulation have been repeatedly implicated in the pathogenesis of hypertension in PIH $[12,13]$. The development and progression of this disease is characterized by rapid retention of sodium, resulting in sudden increases in maternal body weight, followed by hypertension, proteinuria, and often edema [2]. An explanation for the derangement in sodium metabolism and the development of hypertension is not clear. However, these clinical observations have led many obstetricians/gynecologists, hoping to prevent or minimize symptoms of the disease, to advise patients to alter normal patterns of dietary sodium intake. Yet, GANT et al. [14], have shown an increased responsiveness to A-II in subjects destined to develop PIH long before clinical evidence of the disease is apparent.

The data from the current investigation suggests both plasma A-II and mean arterial pressure are functions of sodium balance during pregnancy. Plasma levels of A-II were decreased significantly in the presence of high salt intake and the respective animals became hypertensive. Levels of A-II increased significantly during salt restriction, but animals remained normotensive. Mechanisms responsible for the hypertension in the salt loaded group may be related to volume loading or other factors not investigated in this study. A positive correlation between levels of A-II and mean arterial pressure was found in all three groups. However, the correlation only reached statistical significance in the dietary manipulated groups.

Explanations for the apparent stronger relationship between A-II and blood pressure in the sodium altered state when compared to the sodium replete state are speculative. A possible explanation may be the limited number of animals studies, although each group was similar in number investigated. Another explanation may be the assay for A-II, in which the A-II antibody cross reacts with peptides other than A-II. Interassay variations for this hormone, in our laboratory, usually range from 10.5 to $12.5 \%$. The variation in this study was slightly increased at $14.7 \%$.

Experimental evidence in humans shows that salt loading normal gravidas results in excretion of excessive sodium, allowing the gravida to remain in balance [3]. During salt restriction, much sodium is lost before adjustment in sodium intake and output can be made and balance is regained [9]. Similar observations were made in this study using an animal model. Urinary sodium excretion was increased in the salt loaded animals and was decreased in the salt restricted group. However, the loss of sodium in urine may have occurred in the salt restricted group prior to collection for analysis. Serum sodium was significantly decreased in the salt restricted group and supports this possibility. These findings suggest this model is suitable for studying the interrelationships of sodium balance, blood pressure, and A-II.

The findings in the current study require confirmation in the human. Sodium intake may modify the relationship between A-II and blood pressure. Thus, sodium balance could modify measured A-II levels and the relationship of these levels to blood pressure. Attempts to resolve existing conflicts in observations made by WEIR et al. [14] and SYMOND et al. [11] in regard to plasma A-II and blood pressure, should be done with strict attention to the state of sodium balance. 


\section{Summary}

The renin-angiotensin system and dietary sodium have been repeatedly implicated in the pathogenesis of pregnancy induced hypertension (PIH). Mechanisms responsible for increased vascular responsiveness to angiotensin II (A-II) observed in PIH are not completely understood. Plasma A-II levels and blood pressure are functions of sodium balance in the non-pregnant state, but less is known about their relationship during gestation. Plasma levels of A-II increase in normal pregnancy, but the reported levels of this pressor substance circulating in subjects with PIH are in conflict. The pregnant rabbit demonstrates several conditions similar to those found in pregnant human subjects. We used this model to study the effects of dietary sodium manipulation on plasma levels of A-II and mean arterial pressure during late pregnancy in 30 chronically prepared New Zealand white rabbits. The animals were 24 to 28 days gestation (term $30 \pm 1$ day). All animals were maintained on 1 of 3 diets for 8 days prior to operation and for the duration of the investigation: 10 were fed Purina regular chow ( $0.4 \%$ sodium), and permitted to drink $0.9 \%$ saline, 10 were fed trace-sodium diet (Purina 5881-R) and deionized water ad libitum; and 10 were continued on tap water and regular rabbit chow ( $0.4 \%$ sodium) and served as controls. Urines were collected for 24 hours prior to surgery for sodium determination. An indwelling catheter was placed in the carotid artery for blood pressure recording and blood sampling. After a 20 minute stabilization period, mean arterial pressure was repeatedly recorded and blood samples were obtained for determination of A-II levels and sodium concentration. Plasma A-II was determined by RIA. There was positive correlation between plasma A-II and mean arterial pressure in all 3 groups. However, the correlation was statistically significant only in the sodium perturbated group.

Conclusions: Plasma level of A-II is a function of sodium balance and can be manipulated by dietary means. Sodium intake may modify the relationship between A-II and blood pressure and may account for existing conflicts in observations cited in the literature on the interrelationship between these factors.

Keywords: Angiotensin II, animal model, hypertension, pregnancy, sodium.

\section{Zusammenfassung}

Plasma-Angiotensin II- und Blutdruckschwankungen bei unterschiedlichem Salzgehalt der Nahrung

Hinsichtlich der Pathogenese des schwangerschaftsinduzierten Hypertonus (PIH) wurde wiederholt auf die Bedeutung des Renin-Angiotensin-Systems und des Salzgehaltes der Nahrung hingewiesen. Der verantwortliche Mechanismus für die erhöhte Empfindlichkeit der Gefäße gegenüber Angiotensin-II (A-II), wie sie beim PIH beobachtet wird, ist unklar. Plasma-A-II-Spiegel und Blutdruck sind Funktionen des Natriumgleichgewichts im nichtschwangeren Zustand; über die Zusammenhänge während der Schwangerschaft ist jedoch wenig bekannt. Der Plasma-A-II-Spiegel steigt in der normalen Schwangerschaft. Die in der Literatur beschriebenen Werte treffen jedoch für die Träger eines PIH nicht zu. Das schwangere Kaninchen bietet verschiedene mit dem Menschen vergleichbare Bedingungen. Wir benutzten dieses Modell, um den Einfluß des Salzgehaltes der Nahrung auf die PlasmaA-II-Spiegel und den mittleren arteriellen Druck während der Spätschwangerschaft zu untersuchen. Dabei standen uns 30 "New Zealand white rabbits" mit einem Schwangerschaftsalter von $24-28$ Tagen (Termin $30 \pm 1$ Tag) zur Verfügung. Alle Tiere erhielten 8 Tage vor der Operation bzw. für die Dauer der Versuche jeweils 1 von 3 Diäten: 10 wurden mit einer Nahrung, deren Salzgehalt 0,4\% betrug, gefüttert und konnten eine 0,9\%ige Salzlösung trinken, 10 erhielten eine mit Natriumspuren versetzte Diät und deionisiertes Wasser ad libitum und 10 bekamen weiterhin Wasser aus der Tränke und normale Kaninchennahrung $(0,4 \%$ Natrium); letztere dienten als Kontrolle. Vor der Operation wurde der 24-h-Urin zur Bestimmung der Natriumkonzentration gesammelt. Zur Blutdruckmessung und Blutentnahme implantierten wir einen Dauerkatheter in die Arteria carotis. Nach einer Stabilisierungsphase von 20 Minuten wurde der mittlere arterielle Druck wiederholt gemessen und Blut für die Bestimmung von A-II und Natrium entnommen. Das Plasma-A-II wurde radioimmunologisch erfaßt. In allen 3 Gruppen gab es eine positive Korrelation zwischen dem Plasma-A-IISpiegel und dem mittleren arteriellen Druck. Statistisch signifikant war die Korrelation jedoch nur bei den Tieren, die mit einem erhöhten Salzgehalt gefüttert worden waren.

Schlußfolgerungen: der Plasma-A-II-Spiegel ist eine Funktion des Natriumgleichgewichts und kann diätetisch gesteuert werden. Die Natriumaufnahme kann die Beziehung zwischen A-II und Blutdruck modifizieren. Hier liegt vielleicht der Grund für die in der Literatur beschriebenen Widersprüche bezüglich der Zusammenhänge zwischen diesen Faktoren.

Schlüsselwörter: Angiotensin II, Hypertonus, Natrium, Tiermodell, Schwangerschaft.

\section{Résumé}

Modifications de l'angiotensine II plasmatique et de la pression artérielle au cours des manipulations du sodium alimentaire

Le système rénine-angiotensine et le sodium alimentaire ont été impliqués de façon répétée dans la pathogénèse de l'hypertension induite par la grossesse (HIG). Les mécanismes responsables de la réponse vasculaire accrue à l'angiotensine II (A-II) que l'on observe dans l'HIG ne sont pas totalement compris. Les taux plasmatiques d'A-II et la pression artérielle sont fonction de la balance sodée en 
l'absence de grossesse, mais on en connait moins sur leurs relations au cours de la grossesse. Les taux plasmatiques d'A-II augmentent au cours de la grossesse normale, mais les taux rapportés de cette substance pressive circulante chez les patientes présentant une HIG ne sont pas en accord. La lapine gravide manifeste plusieurs modifications similaires à celles trouvées chez les femmes enceintes. Nous avons utilisé ce modèle pour étudier les effets des manipulations du sodium alimentaire sur les taux plasmatiques d'A-II et sur la pression artérielle moyenne, en fin de grossesse, chez 30 lapines blanches de NouvelleZélande chroniques. Les animaux étaient entre le 24 ème et le 28 ème jour de gestation (le terme est de $30 \pm 1$ jours). On a maintenu tous les animaux à 1 des 3 repas pendant les 8 jours précédant l'opération et durant la durée des explorations: 10 ont été nourris régulièrement avec du Purina $(0,4 \%$ de sodium) avec la possibilité de boire une solution saline à $0,9 \%, 10$ ont été nourris avec un régime contenant des traces de sodium (Purina 5881-R) et de l'eau désondée à volonté; les 10 derniers ont continué de boire de l'eau du robinet et de manger l'alimentation habituelle des lapins. Ce groupe a servi de groupe contrôle.On a recueilli les urines des 24 heures précédant l'intervention pour doser le sodium. On a mis en place un cathéter dans la carotide pour enregistrer la pression sanguine et effectuer des prélévements sanguins. Au bout d'une période de stabilisation de 20 minutes, l'enregistrement de la pression artérielle moyenne e été effectué de façon répétée et des prélèvements sanguins ont été effectués pour doser l'A-II et le sodium. Les mesures plasmatiques d'A-II ont été faites par dosage radio-immunologique. Il a été trouvé une corrélation positive dans les 3 groupes entre l'A-II plasmatique et la pression artérielle moyenne. Toutefois, la corrélation n'est statistiquement significative que dans le groupe avec sodium perturbé.

Conclusions: Le taux plasmatique d'A-II est fonction de la balance sodée et peut être manipulé au moyen de régimes. Les entrées de sodium peuvent modifier la relation entre l'A-II et la pression artérielle et peuvent justifier les désaccords existants dans les observations citées dans la littérature sur l'interrelation entre ces facteurs.

Mots-clés: Angiotensine II, grossesse, hypertension, modèle animal, sodium.

\section{Bibliography}

[1] BRUNNER, I. R., P. CHANG, R. WALLACH et al.: Angiotensin II vascular receptors: their avidity in relationship to sodium balance, the autonomic nervous stem, and hypertension. J. Clin. Invest. 51 (1972) 58

[2] CHESLEY, L.: Hypertensive disorders of pregnancy. Appleton-Century-Crofts, New York (1978) 199

[3] CHESlEY, L. C., C. VALENTI, H. REIN : Excretion of sodium loads by nonpregnant and pregnant normal hypertensive, and preeclamptic women. Metabolism 7 (1958) 575

[4] GANT, N. F., G. L. DALEY, S. Chand et al.: A study of angiotensin II pressor response throughout primigravid pregnancy. J. Clin. Invest. 58 (1973) 2682

[5] GOODFRIEND, T. L., D. L. BALL, D. B. FARLEY: Radioimmunoassay of angiotensin. J. Lab. Clin. Med. 72 (1968) 648

[6] LEE, M. I., C. J. HOBEL, H. TODD et al.: Dietary sodium manipulation and vascular responsiveness during pregnancy in the rabbit. Am. J. Obstet. 146 (1983) 930

[7] LEE, M. I., G. K. OAKES, R. LAM et al.: The rabbit: A suitable model for investigation of vascular responsiveness during pregnancy. Clin. Exp. Hyperten. Preg. B 1 (1982) 429

[8] LINDHEIMER, M., A.I.KATZ: Sodium and diuretics in pregnancy. (Editorial) Obstet. and Gynecol. 44 (1974) 434

[9] SARLES, H. E., S. S. HILL, A. L. LEBLANC et al.: Sodium excretion patterns during an following intravenous sodium chloride loads in normal and hyper- tensive pregnancies. Am. J. Obstet. Gynecol. 102 (1968) 1

[10] SEMPLE, P. F., A. S. BOYD, P. M. SAWES et al.: Angiotensin II and its hepatapeptide (2-8), hexapeptide $(3-8)$, and pentapeptide $(4-8)$ metabolites in arterial and venous blood of man. Circ. Res. 39 (1975) 671

[11] SYMONDS, E. M., F. BROUGHTON PIPKIN, D. J. CRAVEN: Changes in the renin-angiotensin system in primigravidae with hypertensive disease of pregnancy. B. Journ. Obstet. Gyn. 82 (1975) 643

[12] TALLEDO, E. E., L. C. CHESLEY, F. P. ZUSPAN: Renin-angiotensin system in normal and toxaemic pregnancies III. Differential sensitivity to angiotensin II and norepinephrine in toxaemia of pregnancy. Am. J. Obstet. Gynecol. 100 (1968) 218

[13] WEIR, R. J., J. J. BROWN, R. FRASER et al.: Relationship between plasma renin, renin-substrate, angiotensin II, aldosterone and electrolytes in normal pregnancy. J. Clin. Endocrinol. Metab. 40 (1975) 108

[14] WEIR, R. J., R. FRASER, A. F. LEVER et al.: Plasma renin, renin substrate, angiotensin II, and aldosterone in hypertensive disease of pregnancy. Lancet 1 (1973) 291

Milton I. Lee, M.D.

Department of Obstetrics and Gynecology

Hutzel Hospital

4707 St. Antoine Boulevard

Detroit, Michigan 48201

USA 
. 